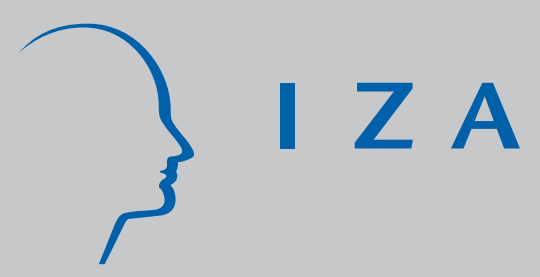

IZA DP No. 656

The Impact of the Unemployment Benefit System on International Spillover Effects

Thomas Beissinger

Oliver Büsse

November 2002 


\title{
The Impact of the Unemployment Benefit System on International Spillover Effects
}

\author{
Thomas Beissinger \\ University of Regensburg and IZA Bonn
}

Oliver Büsse

University of Regensburg

Discussion Paper No. 656
November 2002

IZA

P.O. Box 7240

D-53072 Bonn

Germany

Tel.: +49-228-3894-0

Fax: +49-228-3894-210

Email: iza@iza.org

This Discussion Paper is issued within the framework of IZA's research area Internationalization of Labor Markets. Any opinions expressed here are those of the author(s) and not those of the institute. Research disseminated by IZA may include views on policy, but the institute itself takes no institutional policy positions.

The Institute for the Study of Labor (IZA) in Bonn is a local and virtual international research center and a place of communication between science, politics and business. IZA is an independent, nonprofit limited liability company (Gesellschaft mit beschränkter Haftung) supported by the Deutsche Post AG. The center is associated with the University of Bonn and offers a stimulating research environment through its research networks, research support, and visitors and doctoral programs. IZA engages in (i) original and internationally competitive research in all fields of labor economics, (ii) development of policy concepts, and (iii) dissemination of research results and concepts to the interested public. The current research program deals with (1) mobility and flexibility of labor, (2) internationalization of labor markets, (3) welfare state and labor market, (4) labor markets in transition countries, (5) the future of labor, (6) evaluation of labor market policies and projects and (7) general labor economics.

IZA Discussion Papers often represent preliminary work and are circulated to encourage discussion. Citation of such a paper should account for its provisional character. A revised version may be available on the IZA website (www.iza.org) or directly from the author. 
IZA Discussion Paper No. 656

November 2002

\section{ABSTRACT \\ The Impact of the Unemployment Benefit System on International Spillover Effects}

Based on a two-country model it is scrutinized how the structure of the unemployment benefit system affects the consequences of idiosyncratic labor market shocks on real wages and unemployment in other countries. International spillover effects are caused by changes in world real income. The paper provides new insights on how changes in world real income affect labor demand and the wage bargaining process. The analysis of the interaction of shock spillovers and benefit system focuses on two-tier as well as pure earnings-related and flat-rate benefit systems.

JEL Classification: E24, F41, J23, J51, J65

Keywords: benefit system, unemployment, real wages, open economy, wage bargaining

Corresponding author:

Thomas Beissinger

Department of Economics

University of Regensburg

93040 Regensburg

Germany

Tel.: +499419432740

Fax: +49 9419432735

Email: thomas.beissinger@wiwi.uni-regensburg.de 


\section{Introduction}

With regard to the unemployment problem, macroeconomists and labor economists seem to have reached a consensus, suggesting that any explanation of the divergent unemployment experiences in OECD countries must take account of the interaction of shocks and labor market institutions. ${ }^{1}$ This paper contributes to the analysis of shocks and institutions by focusing on the unemployment and real wage consequences of different unemployment compensation systems in open economies.

Whereas most of the literature has drawn attention to the impact of the benefit level, the structure of the unemployment compensation system may be as or even more important (cf. Manning, 1998). In most OECD countries a two-tier unemployment compensation system exists which comprises earnings-related unemployment insurance and flat-rate unemployment assistance. However, the share of earnings-related benefits in total unemployment compensation significantly varies between countries. Germany and the UK can be interpreted as limiting cases since in Germany both unemployment insurance and unemployment assistance are earnings-related, whereas in the UK both are paid as flat-rate transfers. ${ }^{2}$

In this paper it is analyzed how the benefit system determines the reaction of real wages and unemployment to labor market shocks originating from abroad. The focus on labor market shocks is not arbitrary. For instance, in the European Union fiscal policy has to obey the strict limits on borrowing laid down in the Stability Pact, and monetary policy is primarily concerned about inflation. In such an economic environment the relative performance of economies largely depends on the labor market. However, in open economies labor market shocks in one country will also have an impact on other countries. The shocks considered in our analysis are changes in labor unions' relative bargaining power and/or union preferences, or changes in the generosity of the unemployment compensation system. It will be shown that the impact of labor market shocks on other countries

\footnotetext{
${ }^{1}$ See, for instance, Layard et al. (1991), Nickell (1997), Ljungquist and Sargent (1998), Nickell and Layard (1999) and Blanchard and Wolfers (2000).

${ }^{2}$ The institutional details of unemployment compensation systems are, for instance, described in OECD (1999) and Beissinger (2002), chap. 2.
} 
depends on the unemployment compensation systems in those countries. As an important and novel feature of the analysis it is also demonstrated how idiosyncratic labor market shocks influence the wage bargaining process in open economies.

The remainder of the paper is organized as follows: In Section 2 the analysis is related to previous contributions in the literature. Section 3 introduces the two-country model characterized by monopolistic competition in goods markets and wage bargaining in labor markets. In Section 4 the impact of the benefit system on international spillover effects is considered. The analysis distinguishes between two-tier, pure earnings-related and pure flat-rate benefit systems. Section 5 provides a summary and some conclusions.

\section{Relation to the Literature}

In reaction to Atkinson and Micklewright (1991) who criticized theoretical studies which largely ignored real-world differences in unemployment compensation systems, numerous theoretical and empirical contributions emerged analyzing the impact of benefit systems on the employment performance of an economy. ${ }^{3}$ One branch of this literature focuses on the consequences of earnings-related versus flat-rate benefit systems. For example, Schluter (1997) considers the relative performance of earnings-related and flat-rate benefits with respect to the alleviation of poverty and the reduction of income inequality. Pissarides (1998) demonstrates that the type of unemployment compensation system may play a crucial role in determining the employment effects of tax-rate changes. Egger (2002) compares the consequences of earnings-related and flat-rate benefit systems in right-tomanage and efficient bargaining models. Goerke (2000), Heer and Morgenstern (2000) and Goerke and Madsen (2002) analyze the employment and real wage effects which result if the share of earnings-related unemployment benefits relative to flat-rate transfers is increased, and Bräuninger (2000) establishes a link between the type of unemployment compensation system and the employment performance of different skill groups. With the exception of the latter author, who presents a model of a small open economy, the above cited contributions exclusively concentrate on closed-economy models.

\footnotetext{
${ }^{3}$ See, for instance, Holmlund (1998) for a review of the literature.
} 
In contrast to this literature, our former paper, Beissinger and Büsse (2001), compares pure earnings-related and flat-rate unemployment compensation systems within a twocountry framework. It is demonstrated that a pure earnings-related benefit system partly neutralizes the effects of labor market shocks stemming from abroad since only real wages but not employment are affected. This is in contrast to a flat-rate system in which both unemployment and real wages are influenced by international shock spillovers. Opposite results are obtained for the country where the shock originates. In that country the change in employment is more pronounced if an earnings-related instead of a flat-rate system prevails.

The impact of idiosyncratic labor market shocks on other countries seems to be the implication of a crucial assumption made in Beissinger and Büsse (2001) stating that firms use a Cobb-Douglas technology. In an earnings-related system this assumption leads to a vertical wage-setting curve in real wage/unemployment space, whereas in a flat-rate system the wage-setting curve is downward-sloping . Moreover, in a Cobb-Douglas model international shock spillovers only affect labor demand, whereas the wage bargaining process remains unaffected. Since shock spillovers lead to a shift of the labor demand curve but leave the wage-setting curve unchanged, it seems to be immediately obvious that employment will not change in a benefit system with a vertical (as opposed to a downward-sloping) wage-setting curve.

One aim of our new paper is to scrutinize whether the results of Beissinger and Büsse (2001) are robust to a change in the production function assumed. A natural generalization is to use a CES production technology which implies that the wage-setting curve is downward-sloping in both earnings-related and flat-rate benefit systems. Moreover, we will consider the implications of two-tier benefit systems which have not explicitly been analyzed in our former paper. As a consequence of our generalization it will turn out that not only labor demand but also the wage bargaining process is affected by international shock spillovers. In our view, this aspect of our analysis is of broader interest in its own right. As far as we know, the impact of international spillover effects on the location of the labor demand and wage-setting curve has not yet been analyzed in the literature. We will show how the extent of the shift of both curves depends on the respective unemployment 
compensation system, which enables us to provide a graphical exposition of our analytical results.

\section{The Model}

In the two-country model developed in this paper the goods market is integrated and characterized by monopolistic competition between firms. It is assumed that all goods are tradable, i.e. the nontraded goods sector is neglected. On the labor market wage bargaining takes place at the firm level. The outcome of the wage-setting process is influenced by the relative bargaining power of firms and unions, the preferences of labor unions for employment and wages and the institutional setup of the social security system. It is assumed that countries are different with respect to these variables, but are identical otherwise. The differences in wage setting may lead to country-specific wage and price levels which can persist since migration of the labor force is impeded by cultural and linguistic barriers. Besides the number of households also the number of firms in both countries is exogenously given, which may be due to barriers to market entry provoked by sunk costs. For the ease of exposition it is assumed that unemployment benefits are financed by (lump-sum) taxes on the fixed stock of capital. In this case the government budget constraint and the impact of taxes on the wage-setting process do not have to be taken into account. In our former paper, Beissinger and Büsse (2001), we already demonstrated that the qualitative results are not changed if unemployment benefits are instead financed by a proportional tax on wage income.

The assumption of international heterogeneity of labor market institutions captures important facets of real world economic systems. To take some examples, the theoretical framework can, in principle, be interpreted as describing the interdependencies between member states of the European Union, or between the European Union on the one hand, and the United States on the other. There may be some doubt about whether a theoretical framework based on firm-level wage bargains can produce meaningful results for European economies in which wage bargains often take place at the industry or national level. The well-known hypothesis of Calmfors and Driffill (1988) suggests that there might be a U- 
shaped relationship between the levels of bargained wages and employment on the one hand and the degree of centralization of wage bargaining on the other. Though being restricted to firm-level wage bargains, the following analysis is also relevant for European economies for basically two reasons: First, the focus is not on the explanation of countryspecific levels of unemployment and real wages, but on the changes of these variables which are provoked by international spillover effects. Second, the Calmfors-Driffill hypothesis has been formulated for a closed economy. However, as argued by Danthine and Hunt (1994) and Flanagan (1999), in a model of an open economy with integrated goods markets economic performance becomes more or less independent of bargaining structure.

\subsection{Demand for Labor in Each Country}

In both countries $A$ and $B$ there is a exogenously given number of $G / 2$ single-product firms and $L$ consumers/workers. With respect to consumer preferences we make the following

Assumption 1 Consumer preferences are identical and comprise all goods $Y_{i j}$ of the twocountry world, $i=1 \ldots G / 2, j=A, B$. Preferences are described by a CES utility function of the Dixit and Stiglitz (1977) type with $\eta$ being the constant elasticity of substitution between all goods, $1<\eta<\infty$.

Each consumer is endowed with one unit of labor which is supplied inelastically. Since migration is excluded, labor can only be supplied in the respective home country. Customs duties, value added taxes and transportation costs are neglected in the model. This implies that the price $P_{i j}$ for a specific good is the same for consumers and producers of either country. Taking account of the budget constraint, utility maximization leads to the goods demand functions of each consumer. In order to obtain the goods demand function relevant for the single firm, one has to sum up the demand functions for the respective good across all consumers of both countries.

Lemma 1 Producer of good $i$ in country $j=A, B$ faces the goods demand function $Y_{i j}^{d}=\left(P_{i j} / P\right)^{-\eta}(Y / G), i=1, \ldots, G / 2$, where $Y$ is world real income and $P$ denotes the aggregate price index whose definition corresponds to the CES utility function. 
Proof. See Appendix.

According to Lemma 1, the firm's goods demand function is a negative function of its price (relative to the prices of other firms) and a positive function of world real income. If all firms in the two-country world chose the same price, each firm would obtain the same share of world demand (or equivalently, world real income). The elasticity of the demand for goods is constant and equals $\eta$ (in absolute values). Of course, in general equilibrium world real income $Y$ is itself an endogenous variable, but from the firm's point of view it is taken as exogenous since it is assumed that the number of firms is large. With respect to technology we make

Assumption 2 Technology of firm $i$ in country $j$ is described by a linear-homogeneous CES production function of the form

$$
Y_{i j}=\left[a N_{i j}^{\beta}+(1-a) K_{i j}^{\beta}\right]^{\frac{1}{\beta}}, \quad-\infty<\beta<1, \beta \neq 0, \quad i=1, \ldots, \frac{G}{2}, j=A, B,
$$

where $N_{i j}$ is employment, $K_{i j}$ is the (exogenously given) capital stock, and a is the distribution parameter of the CES production function, with $0<a<1$.

This technology implies a constant elasticity of substitution between capital and labor of $\sigma=1 /(1-\beta)$. As will be shown below, the real wage of firm $i$ in country $j$ (in terms of the aggregate good), $w_{i j}$, is determined in a wage bargain between each firm and the corresponding labor union. With the wage already determined, firms chose the employment level which maximizes profits, leading to

Lemma 2 With monopolistic competition in the goods market the labor demand function $N_{i j}=N^{i j}\left(w_{i j}, Y\right)$ of firm $i$ in country $j$ is a negative function of its real wage and a positive function of world real income. ${ }^{4}$

Proof. See Appendix.

It is assumed that all firms and labor unions of a country are identical. All firms of a country therefore face the same country-specific wage rate $w_{j}$. It follows that the national

\footnotetext{
${ }^{4}$ Since $K_{i j}$ and $G$ are considered to be fixed, they are not taken into account in the labor demand function $N^{i j}(\cdot)$.
} 
levels of employment and the stock of capital are given by $N_{j}=(G / 2) N_{i j}$ and $K_{j}=$ $(G / 2) K_{i j}$. With an exogenously given workforce $L$ in each country, employment $N_{j}$ and the unemployment rate $u_{j}$ are negatively related via $N_{j}=\left(1-u_{j}\right) L$. The labor demand function of each country can therefore also be expressed in terms of the unemployment rate:

Lemma 3 The inverse labor demand function of country $j=A, B, w_{j}=n^{j}\left(u_{j}, Y\right)$, is a positive function of both the country-specific unemployment rate $u_{j}$ and world real income $Y$.

Proof. See Appendix

The fact that labor demand is a function of world real income is of uttermost importance for the results of this paper. All other things being constant, an increase in aggregate income $Y$ leads to a rise in the firm's relative price $p_{i j} \equiv P_{i j} / P$ and thereby to a rise of marginal revenue. As a consequence, firms increase labor demand which reduces the marginal product and $p_{i j}$ until the first order condition for a profit maximum is restored. As will be shown in more detail below, world real income depends on the production levels (and therefore on the factor inputs) of both countries. As a result, labor demand in one country also depends on labor demand in the other country. In the following the impact of aggregate income on marginal revenue and hence labor demand will be called the aggregate income effect.

\subsection{Wage Setting in Each Country}

In both countries wage bargaining takes place at the firm level. It is assumed that labor unions' preferences can be described by the following utility function.

Assumption 3 The utility function $J_{i j}$ of labor union $i$ in country $j$ is given by

$$
J_{i j}=N_{i j}^{\phi_{j}}\left[w_{i j}-z_{j}\right], \quad \phi_{j}>0, \quad i=1, \ldots, \frac{G}{2}, \quad j=A, B,
$$

where $\phi_{j}$ represents labor unions' preferences for employment relative to wages, and $z_{j}$ denotes the expected real income of a worker who loses his job in the firm under consideration. 
The parameter $\phi_{j}$ is introduced to explicitly take account of changes in labor union's wage bargaining policy caused by a change in preferences. ${ }^{5}$ It was already pointed out that unemployment benefits are financed by taxes levied on the fixed stock of capital. Since payroll taxes and taxes on wage income are neglected, the real wage $w_{i j}$ is the same for employers and employees. It is determined in an asymmetric Nash bargain in which $\chi_{j}$ determines the bargaining power of labor unions in country $j, 0<\chi_{j}<1$. In the following, we will restrict the analysis to the case where the elasticity of substitution between capital and labor, $\sigma$, is less than one. ${ }^{6}$ The bargaining result is summarized in

Lemma 4 It is assumed that the elasticity of substitution between labor and capital is less than one. The real wage determined in the firm-level Nash bargain then is set as markup $m_{i j}$ on the expected alternative income $z_{j}$ according to

$$
w_{i j}=m_{i j} z_{j}, \quad m_{i j}=m^{i j}\left(w_{i j}, Y, \phi_{j}, \chi_{j}\right) \equiv \frac{\mu_{i j}}{\mu_{i j}-1},
$$

with $\mu_{i j}=\mu^{i j}\left(w_{i j}, Y, \phi_{j}, \chi_{j}\right) \equiv \phi_{j} \varepsilon_{i j}^{N W}\left(N^{i j}\left(w_{i j}, Y\right)\right)+\frac{1-\chi_{j}}{\chi_{j}} \frac{\kappa \varepsilon_{i j}^{Y N}\left(N^{i j}\left(w_{i j}, Y\right)\right)}{1-\kappa \varepsilon_{i j}^{Y N}\left(N^{i j}\left(w_{i j}, Y\right)\right)}$, where $\varepsilon_{i j}^{N W}$ denotes the elasticity of labor demand with respect to the real wage (in absolute values) and $\varepsilon_{i j}^{Y N}$ is the elasticity of output with respect to employment. ${ }^{7}$

Proof. See Appendix.

The fact that the wage markup is a function of the real wage and world real income complicates the analysis for basically two reasons. First, the dependence of $m_{i j}$ on $w_{i j}$ implies that an explicit solution for the firm's real wage cannot be derived. And second, the dependence of $m_{i j}$ on $Y$ implies that the bargained real wage in each country is a function of world real income and therefore of the employment level in the other country.

\footnotetext{
${ }^{5}$ For similar specifications of labor unions' preferences see, for example, Abowd and Lemieux (1993) and Nickell (1999) for $\phi=1$, and Manning $(1991,1993)$ allowing for $\phi \neq 1$.

${ }^{6}$ This assumption guarantees that the maximum of the Nash product is found by the corresponding first-order condition. An elasticity $\sigma<1$ also leads to a downward-sloping wage-setting curve in real wage-unemployment space. It must be stressed that the assumption $\sigma<1$ is not very restrictive since there is compelling empirical evidence that the elasticity of substitution between labor and capital is lower than one, cf. Hamermesh (1993), chap. 3, and Chung (1994).

${ }^{7}$ It must hold that $\mu_{i j}>1$ in order to guarantee that $w_{i j}>0$.
} 
In other words: the aggregate income effect not only works via the labor demand equation, but also via the wage-setting equation.

Lemma 5 With $\sigma<1$, the partial derivatives of the wage-markup function have the following signs: $m_{w_{i j}}^{i j}<0, m_{Y}^{i j}>0, m_{\phi_{j}}^{i j}<0$ and $m_{\chi_{j}}^{i j}>0$.

Proof. See Appendix.

According to Lemma 5, an increase in world real income leads to an increase of the wage markup. The reason for this important result is evident from the proof of Lemma 5 in the Appendix. On the one hand, a higher $Y$ leads to a lower labor demand elasticity which cet. par. increases wage pressure. On the other hand a higher $Y$ also reduces the elasticity of the firm's profits with respect to the wage which reduces the firm's position in the Nash bargain. The latter effect is an additional reason for higher wage pressure.

For the derivation of the aggregate wage-setting curve one must take the definition of $z_{j}$ into account. It is assumed that

$$
z_{j}=\left(1-\theta^{j}\left(u_{j}\right)\right) w_{j}+\theta^{j}\left(u_{j}\right) s_{j}, \quad 0<\theta^{j}<1, \quad \theta_{u_{j}}^{j}>0, \quad j=A, B .
$$

The function $\theta^{j}$ denotes the probability of finding a job elsewhere in that country, which depends on the respective unemployment rate $u_{j}{ }^{8}$ The variable $w_{j}$ is the average real wage level (in terms of the aggregate good) and $s_{j}$ is the real unemployment compensation in country $j$, defined as

$$
s_{j}=\gamma_{j} \rho_{j} w_{j}+\left(1-\gamma_{j}\right) b_{j}=\tilde{\rho}_{j} w_{j}+\tilde{b}_{j}, \quad 0 \leq \gamma_{j} \leq 1, \quad 0<\rho_{j}<1, \quad b_{j}>0,
$$

where $\gamma_{j}$ denotes the share of earnings-related benefits in total unemployment compensation. The parameter $\rho_{j}$ reflects the ratio of benefits to wages in the earnings-related component, $b_{j}$ denotes flat-rate benefits, $\tilde{\rho}_{j} \equiv \gamma_{j} \rho_{j}$ and $\tilde{b}_{j} \equiv\left(1-\gamma_{j}\right) b_{j} \cdot{ }^{9}$ In the case of a

\footnotetext{
${ }^{8}$ In the literature sometimes the special case $\theta^{j}=u_{j}$ is considered. However, it follows from an intertemporal bargaining framework that the correct specification is based on the more general function $\theta^{j}$ which, besides unemployment, would also depend on parameters such as the discount rate and the entry rate into unemployment. For details see, for instance, Layard and Nickell (1990) and Beissinger and Egger (2001).

${ }^{9}$ In accordance with the literature it is assumed that earnings-related benefits are a function of the average wage level in the respective country. This guarantees that $z_{j}$ is exogenous in the firm-level
} 
pure earnings-related unemployment compensation system, $\gamma_{j}=1$, which implies $\tilde{b}_{j}=0$. If benefits are paid as flat-rate transfers, $\gamma_{j}=0$, which leads to $\tilde{\rho}_{j}=0$. In the following, we will first assume that a two-tier unemployment compensation system prevails in both countries, which implies $\tilde{\rho}_{j}>0$ and $\tilde{b}_{j}>0$ for $j=A, B$. At a later stage of the analysis, we will consider the special cases where either a pure earnings-related or pure flat-rate system prevails in both countries. Since within a country all firms and unions are identical, $w_{i j}=w_{j}$ must hold in equilibrium. The aggregate wage-setting equation can then be characterized by

Lemma 6 The wage-setting equation is a function $w_{j}=w^{j}\left(u_{j}, Y, \phi_{j}, \chi_{j}, \tilde{\rho}_{j}, \tilde{b}_{j}\right)$, with $w_{u_{j}}^{j}<0, \quad w_{Y}^{j}>0 \quad w_{\phi_{j}}^{j}<0, \quad w_{\chi_{j}}^{j}>0, \quad w_{\tilde{\rho}_{j}}^{j}>0, \quad w_{\tilde{b}_{j}}^{j}>0, \quad j=A, B$.

Proof. See Appendix.

\subsection{Aggregate Output and its Impact on Labor Demand and Wage Setting}

To close the model, aggregate output is written as a function of the national production levels, which in turn depend on factor inputs. This leads to

Lemma 7 Aggregate output is a function of national unemployment rates, defined by $Y=y\left(u_{A}, u_{B}\right) \quad$ with $\quad y_{u_{j}}<0, \quad j=A, B$.

Proof. See Appendix

The dependence of aggregate output on the unemployment rates of both countries has to be taken into account in the aggregate labor demand function and in the wage-setting equation of each country.

bargain. In some countries there is a ceiling on unemployment insurance below or near average earnings which corresponds to the theoretical assumption, see Beissinger (2002), chap. 2. Beissinger and Egger (2001) discuss within a dynamic wage bargaining model the complications which arise if this assumption is abandoned. 


\section{Proposition 1 (Aggregate Labor Demand Curve in Each Country)}

The aggregate labor demand curve is described by $w_{j}=n^{j}\left(u_{j}, y\left(u_{A}, u_{B}\right)\right)$, for $j=A, B$. The curve is upward-sloping in real wage-unemployment space. An increase in the unemployment rate abroad shifts the labor demand curve in the country under consideration downwards and vice versa.

Proof. See Appendix.

The properties of the wage-setting curve are summarized in

\section{Proposition 2 (Aggregate Wage-Setting Curve in Each Country)}

The aggregate wage-setting curve is $w_{j}=w^{j}\left(u_{j}, y\left(u_{A}, u_{B}\right), \tilde{\rho}_{j}, \phi_{j}, \chi_{j}, \tilde{b}_{j}\right)$, for $j=A, B$. This curve is downward-sloping in real wage-unemployment space. An increase in the unemployment rate abroad shifts the wage-setting curve in the country under consideration downwards and vice versa. The signs of the remaining partial derivatives follow from Lemma 6 .

Proof. See Appendix.

Note that the effect of a change in the "own" unemployment rate on aggregate income has an influence on the slope of the labor demand curve and wage setting curve, whereas a change in the unemployment rate abroad leads to a shift of both curves.

\section{The Effects of Country-Specific Labor Market Shocks}

The labor market equilibrium in each country is characterized by the intersection of the respective aggregate labor demand curve and wage-setting curve. The comparative-static analysis is therefore based on the two-equation system

$$
n^{j}\left(u_{j}, y\left(u_{A}, u_{B}\right)\right)-w^{j}\left(u_{j}, y\left(u_{A}, u_{B}\right), \tilde{\rho}_{j}, \phi_{j}, \chi_{j}, \tilde{b}_{j}\right)=0, \quad j=A, B
$$

for the two unknowns $u_{A}$ and $u_{B}$. Inserting the solution for the unemployment rates in the labor demand equation (or wage-setting equation) of each country leads to the solution for real wages, $w_{A}$ and $w_{B}$. For the comparative-static analysis we make the following 
Assumption 4 In Country $A$ an (adverse or favorable) labor market shock occurs, i.e. the variable $x_{A}$ changes, where $x_{A} \in \mathbb{X}_{A}=\left\{\phi_{A}, \chi_{A}, \tilde{\rho}_{A}, \tilde{b}_{A}\right\}$. The respective variables for country $B$ remain unchanged.

\subsection{Two-Tier Unemployment Compensation System}

It is first assumed that $\tilde{\rho}>0$ and $\tilde{b}_{j}>0$ for $j=A, B$, i.e. a two-tier unemployment compensation system prevails in both countries. For the comparative-static effects in country $B$ the following result is important:

\section{Proposition 3 (Aggregate Income Effect in Two-Tier Benefit System)}

In the case of an adverse (favorable) labor market shock in country $A$, the resulting downward (upward) shift of country B's labor demand curve is stronger than the downward (upward) shift of country B's wage-setting curve.

Proof. See Appendix.

In the case of a two-tier system the following results with respect to unemployment and real wages are obtained:

\section{Proposition 4 (Results for Two-Tier Benefit System)}

If a two-tier unemployment compensation system prevails in both countries, labor market shocks in one country have an impact on real wages and unemployment in both countries. An adverse labor market shock in country $A$ leads to a higher unemployment rate and higher real wages in that country. In the other country the unemployment rate also increases, whereas real wages decline. A favorable labor market shock in country $A$ has the opposite effects: it leads to a decline in unemployment in both countries, reduces real wages in country $A$ and causes a rise in real wages in country $B$.

Proof. See Appendix.

Figure 1 may help to clarify these results. Note that the location of the labor demand curve (LD-curve) and the wage-setting curve (WS-curve) depends on the unemployment rate in the other country due to the aggregate income effect. In Figure 1(a) the initial labor market equilibrium for country $A$ is determined by the labor demand curve $\operatorname{LD}\left(u_{0}^{B}\right)$ and the wage-setting curve $\mathrm{WS}_{0}\left(u_{0}^{B}\right)$ (point $\mathrm{A}$ ). Now consider the consequences of an 


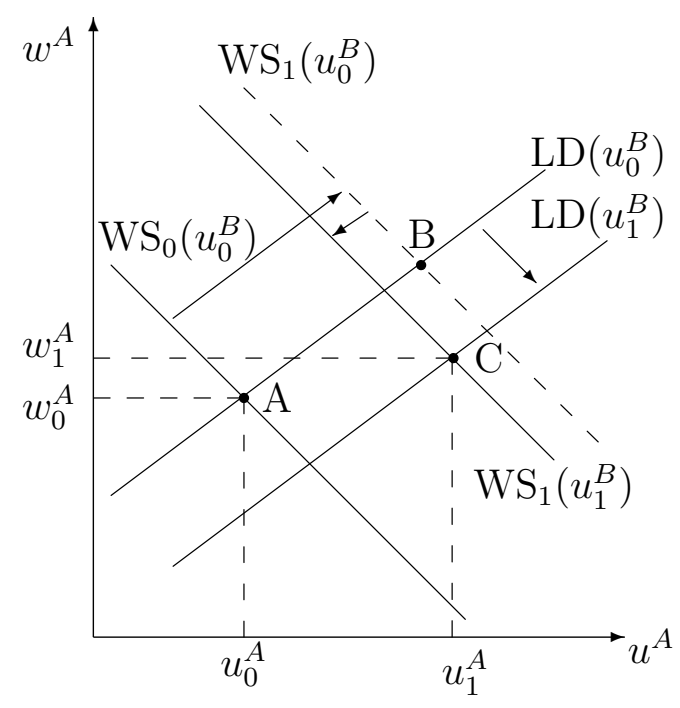

(a) Country $A$

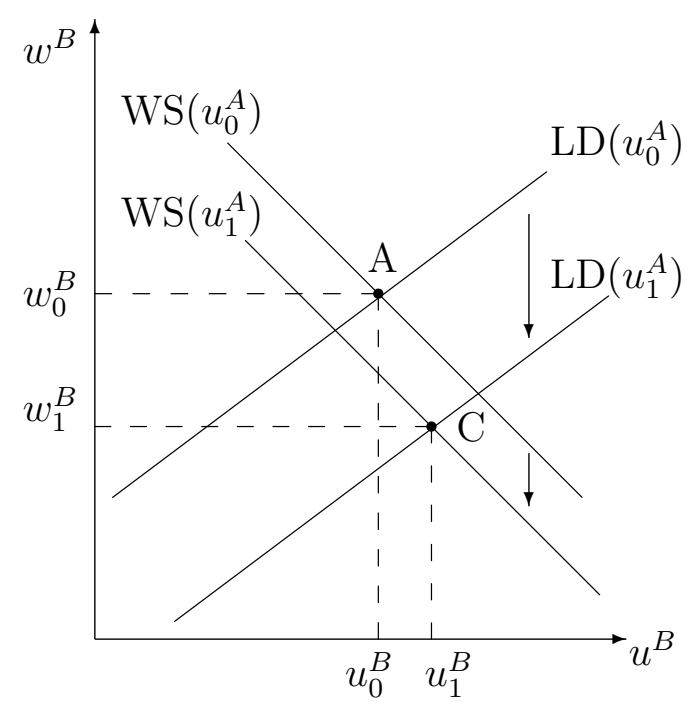

(b) Country $B$

Figure 1: The Consequences of an Adverse Labor Market Shock in Country $A$ if a TwoTier Benefit System Prevails in Both Countries

adverse labor market shock in country $A$, which might be provoked by a rise in labor union power in that country. Since $w_{\chi_{A}}^{A}>0$, the rise in $\chi_{A}$ will shift the wage-setting curve upwards to $\mathrm{WS}_{1}\left(u_{0}^{B}\right)$. In a closed economy, the new equilibrium would be given by point $\mathrm{B}$, with national real wages and unemployment increasing as depicted. However, in the open economy considered here, there are also reactions of firms and labor unions in country $B$ due to the decline of aggregate output (Figure 1(b)). A reduction in $Y$ leads to a decline in marginal revenue with respect to employment, which implies that labor demand decreases. The decline in labor demand corresponds to the downward (rightward) shift of the LD-curve.

A decline in $Y$ also implies that the labor demand elasticity and the elasticity of marginal revenue with respect to employment increase. ${ }^{10}$ As a consequence, the wage markup on the expected alternative income declines for every labor union implying lower wage pressure at the national level. This effect leads to a downward shift of the WS curve in country $B$. According to Proposition 3, the aggregate income effect has a stronger

\footnotetext{
${ }^{10}$ This is evident in the proof of Lemma 5 .
} 
impact on the labor demand curve than on the wage-setting curve. As a consequence, the unemployment rate in country $B$ is rising and real wages are falling.

The increase in unemployment leads to a further reduction of aggregate output, implying a feedback effect on country $A$. In Figure 1(a), this is depicted by a corresponding downward shift of the WS and LD curve in country $A$, leading to a further increase of the unemployment rate and a downward pressure on real wages. Despite the latter effect, it is shown in the proof of Proposition 4 that in the new equilibrium given by point $\mathrm{C}$ real wages in country $A$ will be higher than before. It can be concluded that those still employed in country $A$ are profiting from real wage gains whereas the employees in country $B$ are adversely affected in two ways: firstly, the real wage push in country $A$ causes unemployment in country $B$ to rise and secondly, the remaining employees have to accept lower real wages.

If the comparative-static results for the unemployment rates of both countries are taken into account in the remaining equations of the model, the following results can additionally be derived:

Corollary 1 If a two-tier unemployment compensation system prevails in both countries, an adverse labor market shock in country $A$ also has the following consequences: $Y_{A}$ and $Y_{B}$ decline, $Y_{A} / Y_{B}$ declines, $Y$ declines, $p_{A}$ increases, $p_{B}$ declines and hence the real exchange rate $p_{A} / p_{B}$ increases. The reverse signs apply for a favorable labor market shock in country $A$.

Proof. See Appendix.

In this model all goods produced in the two-country world are traded between countries. Hence, $p_{A} / p_{B}$ also denotes the price ratio of exported relative to imported goods. An increase in $p_{A} / p_{B}$ in the case of an adverse labor market shock means that country $A$ experiences a real appreciation. The change in relative prices shifts relative demand towards country $B$. However, the favorable relative price effect does not prevent the unemployment rate in country $B$ from rising. The reason is that the (negative) aggregate income effect is stronger than the relative price effect. At first glance one could suspect that a high elasticity of substitution between goods might modify this result, since in this 
case a given change in relative prices would induce a strong relative demand shift in favor of country $B$. However, this would also lead to a more pronounced rise in country $A$ 's unemployment rate, implying a larger reduction of aggregate output. Thus, the aggregate income effect is dominant even if the demand for goods is highly elastic.

\subsection{Earnings-Related Unemployment Compensation System}

As a special case it is now assumed that a (pure) earnings-related benefit (ERB) system exists in both countries, which implies that $\gamma_{j}=1$ in eq. (2). As a consequence, $\tilde{b}_{j}=0$, and unemployment compensation in each country simply is $s_{j}=\rho_{j} w_{j}$, for $j=A, B$. For the comparative-static effects in country $B$ the following result is important:

\section{Proposition 5 (Aggregate Income Effect in ERB System)}

In the case of an adverse (favorable) labor market shock in country $A$, the labor demand and wage-setting curve in country $B$ are shifting downwards (upwards) by the same amount.

Proof. See Appendix.

This proposition immediately leads to

\section{Proposition 6 (Results for ERB System)}

If an earnings-related benefit system prevails in both countries, country-specific labor market shocks only have an impact on real wages in the other country. An adverse (favorable) labor market shock in country A leads to higher (lower) unemployment and higher (lower) real wages in that country. In country $B$ real wages decline (rise). In both cases the unemployment rate in country $B$ is not affected.

Proof. See Appendix.

These results are illustrated in Figure 2. In Figure 2(a) the initial labor market equilibrium

for country $A$ is determined by the labor demand curve $\operatorname{LD}\left(u_{0}^{B}\right)$ and the wage-setting curve $\mathrm{WS}_{0}\left(u_{0}^{B}\right)$ (point A). Now consider again an increase in union power in country $A$, which shifts the wage-setting curve to $\mathrm{WS}_{1}\left(u_{0}^{B}\right)$. As a consequence, unemployment and real wages are higher (point $\mathrm{B}$ ). The rise in $u^{A}$ affects the labor demand and wage-setting curve in country $B$, leading to a downward shift of both curves which is of equal size 


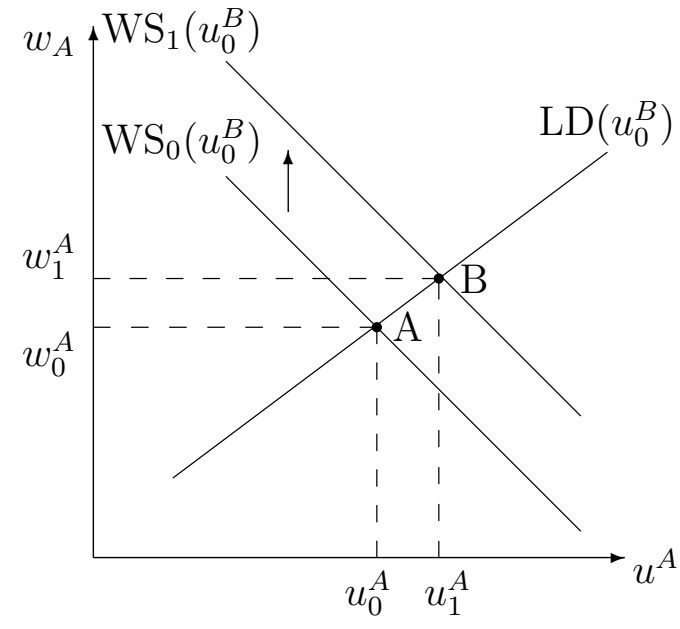

(a) Country $A$

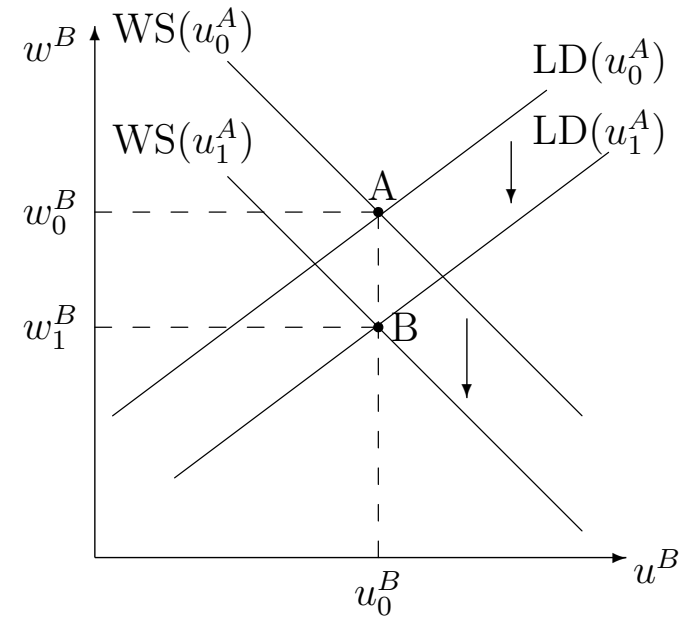

(b) Country $B$

Figure 2: The Consequences of an Adverse Labor Market Shock in Country $A$ if an Earnings-Related Benefit System Prevails in Both Countries

in Figure 2(b). As a consequence, the new equilibrium is characterized by an unchanged unemployment rate $u_{0}^{B}$ and lower real wages $w_{1}^{B}$ (point B). With $u^{B}$ remaining unchanged, there is no repercussion effect on country $A$. Corollary 1 must be slightly modified to

Corollary 2 If a pure earnings-related unemployment compensation system prevails in both countries, an adverse labor market shock in country A also has the following consequences: $Y_{A}$ declines, whereas $Y_{B}$ remains unchanged, leading to a decline in $Y_{A} / Y_{B}$ and $Y$. Moreover, $p_{A}$ increases, $p_{B}$ declines and hence the real exchange rate $p_{A} / p_{B}$ increases. The reverse signs apply for a favorable labor market shock in country $A$.

Proof. Since $u_{B}$ remains constant and the stock of capital is fixed, also $Y_{B}$ is unaffected. The marginal product of labor in country $B$ remains unchanged. With these modifications, the proof is analogous to the proof of Corollary 1.

The analysis in this subsection demonstrates that country B's employment level is not affected by labor market shocks stemming from abroad if a pure earnings-related benefit system prevails in this country. The same "employment neutrality result" has been obtained in Beissinger and Büsse (2001) within a Cobb-Douglas model in which the wagesetting curve in the pure ERB system turns out to be vertical. This result does therefore 
not depend on the wage-setting curve to be vertical. The economic intuition behind this result rather lies in the fact that in an ERB system the impact on wages is amplified because unemployment benefits move in the same direction as wages. In other words: country $B$ 's real wage response to labor market shocks stemming from abroad is flexible enough to keep the level of employment unchanged.

\subsection{Flat-Rate Unemployment Compensation System}

In this section it is assumed that $\tilde{b}_{j}>0$ and $\tilde{\rho}_{j}=0$, for $j=A, B$, i.e. a pure flat-rate benefit (FRB) system exists in both countries. It turns out that the analysis in this case resembles the analysis of the two-tier unemployment compensation system.

\section{Proposition 7 (Aggregate Income Effect in FRB System)}

In the case of an adverse (favorable) labor market shock in country $A$, the resulting downward (upward) shift of country B's labor demand curve is stronger than the downward (upward) shift of country B's wage-setting curve.

Proof. See Appendix.

Proposition 7 implies that the graphical analysis in the case of the two-tier unemployment compensation system (Figure 1) can also be applied if a pure flat-rate benefit system prevails in both countries, which means that the same qualitative results are obtained.

\section{Proposition 8 (Results for FRB System)}

If a pure flat-rate unemployment compensation system prevails in both countries, the same qualitative results as stated in Proposition 4 and Corollary 1 are obtained.

Proof. Taking account of Proposition 7, the proof of Proposition 4 can also be applied to the model with pure flat-rate unemployment benefits in both countries. Then the results of Corollary 1 also follow.

Although in a pure flat-rate unemployment compensation system the same qualitative results as in a two-tier system are obtained, the quantitative implications are different. This will be discussed in more detail in the following section. 


\subsection{The Implications of Different Unemployment Compensation Systems for Country $B$}

The emphasis in this section will be placed on the consequences of different benefit systems for country $B$. The analysis will be facilitated by the following proposition.

\section{Proposition 9 (Comparison of Two-Tier and Flat-Rate Benefit System)}

In a two-tier unemployment compensation system the wage-setting curve is steeper than in a pure flat-rate benefit system. A given change in the unemployment rate abroad leads to a stronger shift of the wage-setting curve if a two-tier system instead of a flat-rate system prevails.

Proof. See Appendix

Based on this proposition, interesting results for country $B$ can be derived. We have already demonstrated that an adverse labor market shock in country $A$ does not affect employment in country $B$ if an earnings-related benefit system prevails in that country. However, with a two-tier or a flat-rate benefit system, unemployment in country $B$ increases. It can be concluded that the increase in unemployment in the latter cases must be attributed to the flat-rate component of unemployment benefits. It might therefore be suspected that for a given unemployment compensation system in country $A$, the increase in unemployment in country $B$ is stronger in a pure flat-rate benefit system than in a two-tier system.

This supposition is corroborated by Figure 3, which depicts the situation for country $B$ in the case of both a two-tier and a flat-rate unemployment compensation system. The wage-setting curves with solid (dashed) lines correspond to a two-tier (flat-rate) unemployment compensation system. Due to Proposition 9 the WS curve in the two-tier system is steeper than the $\overline{\mathrm{WS}}$ curve which corresponds to the flat-rate system. For both systems, the initial equilibrium is characterized by an unemployment rate $u_{0}^{B}$ and a real wage $w_{0}^{B}$. It is assumed that country $A$ is hit by an adverse labor market shock. For the following considerations the benefit system in country $A$ is taken to be given, but which type of benefit system prevails is not relevant. Due to the adverse labor market 


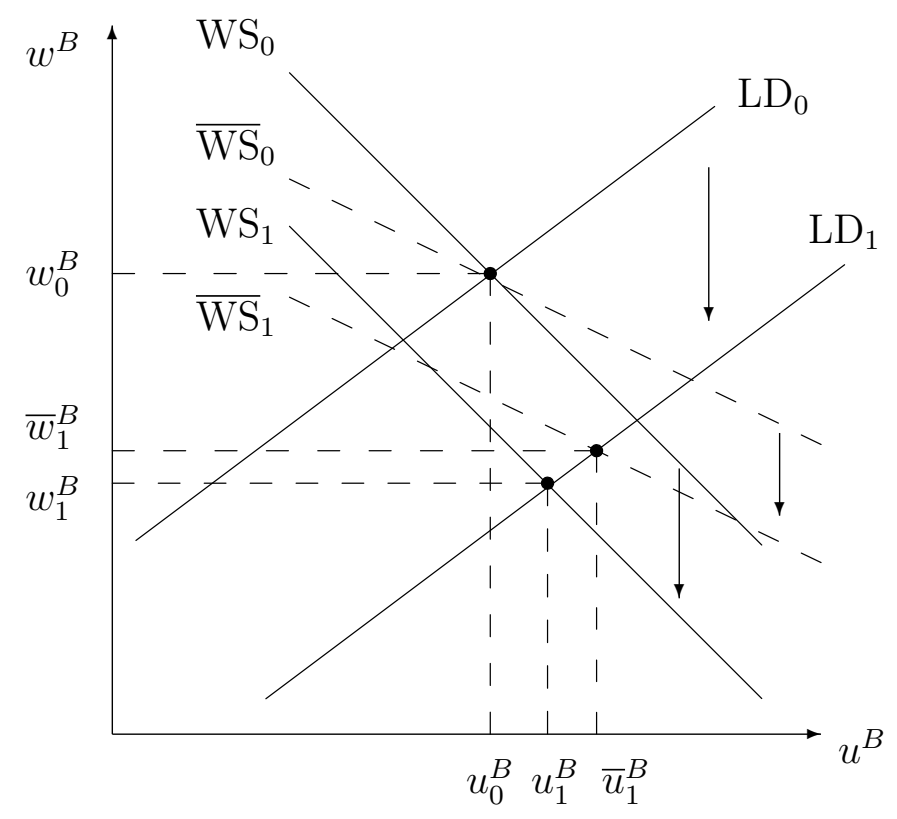

Figure 3: A Comparison of a Two-Tier Unemployment Compensation System and a FlatRate Benefit System for Country $B$

Notes: It is assumed that an adverse labor market shock occurs in country A. The wage-setting curves with solid (dashed) lines result in a two-tier (flat-rate) unemployment compensation system.

shock, unemployment rises in country $A{ }^{11}$ The increase in $u_{A}$ leads to a downward shift of both labor demand and wage-setting curve in country $B$. It has already been shown in Proposition 3 and Proposition 7 that the downward-shift of the wage-setting curve in the two-tier as well as the flat-rate system is less pronounced than the shift of the labor demand curve. Moreover, due to Proposition 9 the shift of the WS curve is stronger than the shift of the $\overline{\mathrm{WS}}$ curve. The new equilibrium in the two-tier system is given by $\left(u_{1}^{B}, w_{1}^{B}\right)$, whereas in the flat-rate system $\left(\bar{u}_{1}^{B}, \bar{w}_{1}^{B}\right)$ results. Hence, it can be seen that, on the one hand, the increase in unemployment in country $B$ is stronger if a flat-rate benefit system prevails. On the other hand, the decline in real wages is stronger if a two-tier benefit system exists.

\footnotetext{
${ }^{11}$ Of course, it is clear from the analysis so far, that the extent of the unemployment increase also depends on the unemployment compensation system in country $A$.
} 
In the same way the results for a favorable labor market shock in country $A$ can be derived. In this case the labor demand curve and wage-setting curve in country $B$ shift upwards. The increase in employment is then more pronounced in a pure flat-rate benefit system than in a two-tier system. The results are summarized in the following proposition, in which additionally the results for the earnings-related benefit system are taken into account.

\section{Proposition 10 (Results for Country $B$ )}

If an adverse (favorable) labor market shock occurs in country $A$, country $B$ experiences

the greatest rise (decline) in unemployment in a flat-rate benefit system, a less pronounced rise (decline) in unemployment in a two-tier system and no change in unemployment in an earnings-related system. The strongest decline (rise) in real wages occurs in an earningsrelated benefit system and the lowest decline (rise) in a flat-rate system. In a two-tier benefit system the real wage response lies in between these two cases.

Proof. The results for the flat-rate system and the two-tier system are evident from Figure 3. In an earnings-related benefit system the shift in the wage-setting curve is equal to the shift of the labor demand curve. Hence, the change in real wages corresponds to the vertical shift of the labor demand curve.

According to Proposition 10 the real wage flexibility is the lower the higher the share of flat-rate benefits, implying stronger employment effects of international shock spillovers.

\section{$5 \quad$ Summary and Conclusions}

Based on a two-country model with monopolistic competition in goods markets and wage bargaining in labor markets it is scrutinized how the unemployment compensation system affects the consequences of international shock spillovers on real wages and unemployment. The shocks considered are country-specific changes in the level of unemployment benefits, changes in labor unions' bargaining power or changes in union preferences. The transmission of these idiosyncratic labor market shocks to other countries is brought about via changes in world real income. The paper provides new insights on how changes in world real income influence labor demand and the wage bargaining process. 
Focusing on the main results of the paper, it is shown that an increase (decline) in the unemployment rate in one country shifts the labor demand curve and the wagesetting curve in the other country downwards (upwards). The extent of the shift of the wage-setting curve in comparison to the shift of the labor demand curve depends on the unemployment compensation system. If benefits are earnings-related, both labor demand and wage-setting curve are shifting to the same extent. In this case labor market shocks stemming from abroad only affect real wages but leave unemployment unchanged. If instead a two-tier or a flat-rate benefit system prevails, shock spillovers from abroad lead to a more pronounced shift of the labor demand curve relative to the wage-setting curve. This implies that not only real wages but also unemployment is affected by labor market shocks originating abroad. We also compare the relative strength of the effects in two-tier and pure flat-rate systems. It is shown that in a two-tier benefit system the wage-setting curve is steeper than in a pure flat-rate system. Moreover, shock spillovers lead to a stronger shift of the wage-setting curve if a two-tier instead of a flat-rate system prevails.

If these results are taken together, the following conclusion can be drawn: If an adverse (favorable) labor market shock occurs in country $A$, country $B$ experiences the greatest rise (decline) in unemployment in a flat-rate benefit system, a less pronounced rise (decline) in unemployment in a two-tier system and no change in unemployment in an earnings-related system. The strongest decline (rise) in real wages occurs in an earnings-related benefit system and the lowest decline (rise) in a flat-rate system. In a two-tier benefit system the real wage response lies in between these two cases. As a consequence, if a government wants to prevent employment fluctuations caused by international spillover effects, it should choose a pure earnings-related instead of a two-tier or flat-rate unemployment compensation system. 


\section{Appendix: Proofs}

Proof of Lemma 1. Facing the budget constraint $\sum_{j=A, B} \sum_{i=1}^{G / 2} P_{i j} Y_{i j}^{n h}=I^{n h}$, consumer $n$ in country $h$ maximizes utility $U^{n h}=G^{1 /(1-\eta)}\left(\sum_{j=A, B} \sum_{i=1}^{G / 2}\left(Y_{i j}^{n h}\right)^{\kappa}\right)^{(1 / \kappa)}$ with respect to $Y_{i j}^{n h}$, where $\kappa \equiv(\eta-1) / \eta, n=1 \ldots L$ and $h=A, B{ }^{12}$ For an employed (unemployed) consumer income $I^{n h}$ comprises his share of profits and wage income (unemployment benefits). The goods demand functions of the single consumer are $Y_{i j}^{n h}=$ $\left(P_{i j} / P\right)^{-\eta} I^{n h} /(P G)$, where $P \equiv\left(\frac{1}{G} \sum_{j=A, B} \sum_{i=1}^{G / 2} P_{i j}^{1-\eta}\right)^{1 /(1-\eta)}$ denotes the aggregate price index. The demand function $Y_{i j}^{d}$ for the producer of good $i$ in country $j$ is $Y_{i j}^{d}=$ $\left(P_{i j} / P\right)^{-\eta}(1 / G)\left(\sum_{h=A, B} \sum_{n=1}^{L} I^{n h} / P\right)$. World real income in terms of the aggregate good is $Y \equiv \sum_{h=A, B} \sum_{n=1}^{L}\left(I^{n h} / P\right)$. This leads to Lemma 1 .

Proof of Lemma 2. Production is equal to demand, i.e. $Y_{i j}^{d}=Y_{i j}$. Due to Lemma 1 the inverse goods demand function is $p_{i j}=Y_{i j}^{\kappa-1}(Y / G)^{1-\kappa}$, where $p_{i j}$ denotes the firm's relative price (in terms of the aggregate good), i.e. $p_{i j} \equiv P_{i j} / P$, and $0<\kappa<1$. The revenue function of each firm (in terms of the aggregate good) can be written as $R_{i j}=$ $R^{i j}\left(N_{i j}, Y\right)=p_{i j} Y_{i j}=\left[a N_{i j}^{\beta}+(1-a) K_{i j}^{\beta}\right]^{\kappa / \beta}(Y / G)^{1-\kappa}$, where $K_{i j}$ and $G$ are suppressed as arguments of the revenue function. Marginal revenue with respect to employment is

$$
R_{N_{i j}}^{i j}=\kappa \varepsilon_{i j}^{Y N} \frac{Y_{i j}^{\kappa}}{N_{i j}}\left(\frac{Y}{G}\right)^{1-\kappa}>0, \quad \text { with } \quad \varepsilon_{i j}^{Y N}=\varepsilon_{i j}^{Y N}\left(N_{i j}\right)=a\left(\frac{N_{i j}}{Y_{i j}}\right)^{\beta} .
$$

$\varepsilon_{i j}^{Y N}$ is the elasticity of output with respect to employment, with $0<\varepsilon_{i j}^{Y N}<1$. Furthermore, $R_{N_{i j}, Y}^{i j}=(1-\kappa) Y^{-1} R_{N_{i j}}^{i j}>0$, and $R_{N_{i j}, N_{i j}}^{i j}=N_{i j}^{-1}\left[(\kappa-\beta) \varepsilon_{i j}^{Y N}-(1-\beta)\right] R_{N_{i j}}^{i j}<0$, where the negative sign in the latter derivative results because $(\kappa-\beta) \varepsilon_{i j}^{Y N}<1-\beta$ for all permissible values of $\beta, \kappa$ and $\varepsilon_{i j}^{Y N}$. The concavity of the revenue function with respect to employment guarantees that the optimal employment level is found by the first-order condition $R_{N_{i j}}^{i j}-w_{i j}=0$. This equation implicitly determines $N_{i j}$ as a function $N^{i j}\left(w_{i j}, Y\right)$ with $N_{w_{i j}}^{i j}=1 / R_{N_{i j}, N_{i j}}^{i j}<0$ and $N_{Y}^{i j}=-R_{N_{i j}, Y}^{i j} / R_{N_{i j}, N_{i j}}^{i j}>0$.

Proof of Lemma 3. As a first step one has to insert eq. (A.1) in the first-order condition $R_{N_{i j}}^{i j}-w_{i j}=0$. Since $N_{j}=(G / 2) N_{i j}, K_{j}=(G / 2) K_{i j}$ and $N_{j}=\left(1-u_{j}\right) L$, the inverse labor demand function of country $j=A, B$ is

$$
w_{j}=n^{j}\left(u_{j}, Y\right) \equiv \kappa a\left[\left(1-u_{j}\right) L\right]^{\beta-1}\left[a\left[\left(1-u_{j}\right) L\right]^{\beta}+(1-a) K_{j}^{\beta}\right]^{\frac{\kappa-\beta}{\beta}}\left(\frac{Y}{2}\right)^{1-\kappa}
$$

\footnotetext{
${ }^{12}$ The derivation of the firm's goods demand function under monopolistic competition in the goods market follows a standard approach in the macroeconomics literature. See, for instance, Weitzman (1985), Blanchard and Kiyotaki (1987), and Dutt and Sen (1997).
} 
with the partial derivatives $n_{u_{j}}^{j}=\left(w_{j} /\left(1-u_{j}\right)\right)\left[(1-\beta)-(\kappa-\beta) \varepsilon_{j}^{Y N}\right]>0$ and $n_{Y}^{j}=$ $(1-\kappa)\left(w_{j} / Y\right)>0$, where $\varepsilon_{j}^{Y N}=\varepsilon_{j}^{Y N}\left(N_{j}\right) \equiv a\left(N_{j} / Y_{j}\right)^{\beta}$ and $j=A, B . n_{u_{j}}^{j}>0$ since the expression in brackets is positive for all permissible values of $\beta$ and $\kappa$.

Proof of Lemma 4. The bargained real wage is found by maximizing the Nash product

$$
\max _{w_{i j}}\left\{N_{i j}^{\phi_{j}}\left[w_{i j}-z_{j}\right]\right\}^{\chi_{j}}\left\{R^{i j}\left(N_{i j}, Y\right)-w_{i j} N_{i j}\right\}^{1-\chi_{j}}, \quad \text { s.t. } \quad N_{i j}=N^{i j}\left(w_{i j}, Y\right),
$$

for $i=1, \ldots, G / 2$ and $j=A, B$. The first-order condition is

$$
\frac{1}{w_{i j}}\left\{\chi_{j} \frac{w_{i j}}{w_{i j}-z_{j}}+\chi_{j} \phi_{j} N_{w_{i j}}^{i j}(\cdot) \frac{w_{i j}}{N^{i j}(\cdot)}-\left(1-\chi_{j}\right) \frac{w_{i j} N^{i j}(\cdot)}{R^{i j}(\cdot)-w_{i j} N^{i j}(\cdot)}\right\}=0 .
$$

It has to be noted that

$$
\frac{w_{i j} N^{i j}(\cdot)}{R^{i j}(\cdot)-w_{i j} N^{i j}(\cdot)}=\frac{R_{N_{i j}}^{i j}(\cdot) N^{i j}(\cdot) / R^{i j}(\cdot)}{1-R_{N_{i j}}^{i j}(\cdot) N^{i j}(\cdot) / R^{i j}(\cdot)}=\frac{\kappa \varepsilon_{i j}^{Y N}\left(N^{i j}\left(w_{i j}, Y\right)\right)}{1-\kappa \varepsilon_{i j}^{Y N}\left(N^{i j}\left(w_{i j}, Y\right)\right)}
$$

is the elasticity of profits with respect to the real wage. The last expression in eq. (A.5) follows from inserting the terms for $R^{i j}$ and $R_{N_{i j}}^{i j}$ derived in the Proof of Lemma 2. Taking account of eq. (A.5) when solving for $w_{i j}$ in eq. (A.4) leads to Lemma 4. The second-order condition for a maximum of the Nash product requires that

$$
\chi_{j} \frac{\partial\left[w_{i j} /\left(w_{i j}-z_{j}\right)\right]}{\partial w_{i j}}-\chi_{j} \phi_{j} \frac{\partial \varepsilon_{i j}^{N W}}{\partial N_{i j}} \frac{\partial N^{i j}}{\partial w_{i j}}-\left(1-\chi_{j}\right) \frac{\partial\left[\kappa \varepsilon_{i j}^{Y N} /\left(1-\kappa \varepsilon_{i j}^{Y N}\right)\right]}{\partial N_{i j}} \frac{\partial N^{i j}}{\partial w_{i j}}
$$

is negative. The first term in this expression is negative. Furthermore,

$$
\varepsilon_{i j}^{N W}=\frac{1}{(1-\beta)-(\kappa-\beta) \varepsilon_{i j}^{Y N}\left(N_{i j}\right)} \text { and } \frac{\partial \varepsilon_{i j}^{N W}}{\partial N_{i j}}=\frac{(\kappa-\beta)}{\left[\left(1-\beta-(\kappa-\beta) \varepsilon_{i j}^{Y N}\right)\right]^{2}} \frac{\partial \varepsilon_{i j}^{Y N}}{\partial N_{i j}} .
$$

It is assumed that $\sigma<1$ which implies $\beta<0$. As a consequence, $\operatorname{sign}\left(\partial \varepsilon_{i j}^{N W} / \partial N_{i j}\right)=$ $\operatorname{sign}\left(\partial \varepsilon_{i j}^{Y N} / \partial N_{i j}\right)$. Since $\varepsilon_{i j}^{Y N}=a N_{i j}^{\beta}\left[a N_{i j}^{\beta}+(1-a) K_{i j}^{\beta}\right]^{-1}$,

$$
\frac{\partial \varepsilon_{i j}^{Y N}}{\partial N_{i j}}=\beta \frac{\varepsilon_{i j}^{Y N}\left(1-\varepsilon_{i j}^{Y N}\right)}{N_{i j}}<0 \quad \text { if } \beta<0 .
$$

Furthermore, note that

$$
\frac{\partial\left[\kappa \varepsilon_{i j}^{Y N} /\left(1-\kappa \varepsilon_{i j}^{Y N}\right)\right]}{\partial N_{i j}}=\frac{\kappa}{\left(1-\kappa \varepsilon_{i j}^{Y N}\right)^{2}} \frac{\partial \varepsilon_{i j}^{Y N}}{\partial N_{i j}} .
$$

One must also bear in mind that due to Lemma $2, N_{w_{i j}}^{i j}<0$. It follows that all terms in eq. (A.6) are negative. As a result, the second-order condition for a maximum of the Nash product is fulfilled if it is assumed that the elasticity of substitution between labor and capital is less than one. 
Proof of Lemma 5. It holds that $m_{\mu_{i j}}^{i j}<0$, i.e. $m_{i j}$ and $\mu_{i j}$ are negatively related. It is easily computed that $\mu_{\phi_{j}}^{i j}>0$ and $\mu_{\chi_{j}}^{i j}<0$. One also obtains

$$
\mu_{\Omega}^{i j}=\left[\phi_{j} \frac{\partial \varepsilon_{i j}^{N W}}{\partial N_{i j}}+\frac{1-\chi_{j}}{\chi_{j}} \frac{\kappa}{\left(1-\kappa \varepsilon_{i j}^{Y N}\right)^{2}} \frac{\partial \varepsilon_{i j}^{Y N}}{\partial N_{i j}}\right] N_{\Omega}^{i j}, \quad \text { where } \Omega \in\left\{w_{i j}, Y\right\}
$$

$N_{w_{i j}}^{i j}<0$ and $N_{Y}^{i j}>0$ due to Lemma 2. If $\sigma<1$ and therefore $\beta<0$, it also holds that $\partial \varepsilon_{i j}^{Y N} / \partial N_{i j}<0$ due to eq. (A.8) and $\partial \varepsilon_{i j}^{N W} / \partial N_{i j}<0$ due to eq. (A.7). As a result, $\mu_{w_{i j}}^{i j}>0$ and $\mu_{Y}^{i j}<0$.

Proof of Lemma 6. Taking account of Lemma 4, eqs. (1) and (2), and bearing in mind that in equilibrium $w_{i j}=w_{j}$ and $\mu^{i j}=\mu^{j}$, one obtains

$$
\mathcal{F}\left(w_{j}, u_{j}, Y, \phi_{j}, \chi_{j}, \tilde{\rho}_{j}, \tilde{b}_{j}\right)=0, \mathcal{F}(\cdot) \equiv w_{j}\left\{\left(1-\tilde{\rho}_{j}\right)-\left[\mu^{j}\left(w_{j}, Y, \phi_{j}, \chi_{j}\right) \theta^{j}\left(u_{j}\right)\right]^{-1}\right\}-\tilde{b}_{j} .
$$

If $\tilde{b}_{j}>0\left(\tilde{b}_{j}=0\right)$, the term in brackets must be positive (zero) in order to guarantee that $w_{j}>0$. Hence, it must hold that $\left(1-\tilde{\rho}_{j}\right) \mu^{j}\left(w_{j}, Y, \phi_{j}, \chi_{j}\right) \theta^{j}\left(u_{j}\right) \geq 1$. Eq. (A.11) implicitly defines $w_{j}$ as a function of the other variables if $\partial \mathcal{F}(\cdot) / \partial w_{j} \neq 0$. This is the case for $\tilde{\rho}_{j}>0$ and $\tilde{b}_{j} \geq 0$ as well as for $\tilde{\rho}_{j}=0$ and $\tilde{b}_{j}>0$. One obtains

$$
\begin{aligned}
& w_{u_{j}}^{j}=-w_{j} \mu^{j} \theta_{u_{j}}^{j} \Psi_{j}^{-1}<0, \quad w_{Y}^{j}=-w_{j} \theta^{j} \mu_{Y}^{j} \Psi_{j}^{-1}>0, \quad w_{\tilde{\rho}_{j}}^{j}=w_{j}\left(\mu^{j} \theta^{j}\right)^{2} \Psi_{j}^{-1}>0 \\
& w_{\phi_{j}}^{j}=-w_{j} \theta^{j} \mu_{\phi_{j}}^{j} \Psi_{j}^{-1}<0, \quad w_{\chi_{j}}^{j}=-w_{j} \theta^{j} \mu_{\chi_{j}}^{j} \Psi_{j}^{-1}>0, \quad w_{\tilde{b}_{j}}^{j}=\left(\mu^{j} \theta^{j}\right)^{2} \Psi_{j}^{-1}>0,
\end{aligned}
$$

where $\Psi_{j} \equiv \mu^{j} \theta^{j}\left[\left(1-\tilde{\rho}_{j}\right) \mu^{j} \theta^{j}-1\right]+w_{j} \theta^{j} \mu_{w_{j}}^{j}>0$.

Proof of Lemma 7. Since national prices $p_{j}$ (in terms of the aggregate good) may differ, aggregate output has to be written as $Y=p_{A} Y_{A}+p_{B} Y_{B}$. Inserting the inverse goods demand function of each country and the national version of the CES production function into this equation and bearing in mind that $N_{j}=\left(1-u_{j}\right) L$, one obtains:

$$
Y=y\left(u_{A}, u_{B}\right) \equiv 2^{\frac{\kappa-1}{\kappa}}\left(\sum_{j=A, B}\left[a\left(\left(1-u_{j}\right) L\right)^{\beta}+(1-a) K_{j}^{\beta}\right]^{\frac{\kappa}{\beta}}\right)^{\frac{1}{\kappa}}
$$

with $y_{u_{j}}=-(Y / 2)^{1-\kappa}\left(Y_{j}^{\kappa} \varepsilon_{j}^{Y N}\right) /\left(1-u_{j}\right)<0, \quad j=A, B$.

Proof of Proposition 1. According to Lemmas 3 and 7 it holds that $n_{u_{j}}^{j}>0, n_{Y}^{j}>0$, and $y_{u_{j}}<0$ for $j=A, B$. Hence, $\left.\left(\partial w_{j} / \partial u_{k}\right)\right|_{\mathrm{LD}^{j}}=n_{Y}^{j} y_{u_{k}}<0, j \neq k$ and $j, k=A, B$. However, the sign of $\left.\left(\partial w_{j} / \partial u_{j}\right)\right|_{\mathrm{LD}^{j}}$ is not immediately obvious. It holds that

$$
\left.\frac{\partial w_{j}}{\partial u_{j}}\right|_{\mathrm{LD}^{j}}=n_{u_{j}}^{j}+n_{Y}^{j} y_{u_{j}}=\frac{w_{j}}{1-u_{j}}\left[(1-\beta)-(\kappa-\beta) \varepsilon_{j}^{Y N}-(1-\kappa) \varepsilon_{j}^{Y N} 2^{\kappa-1}\left(\frac{Y_{j}}{Y}\right)^{\kappa}\right]>0 .
$$


The positive sign arises because $(1-\beta)>(\kappa-\beta) \varepsilon_{j}^{Y N}+(1-\kappa) \varepsilon_{j}^{Y N}$, where the right-hand side of this inequality is equal to $(1-\beta) \varepsilon_{j}^{Y N}$, and $0<\varepsilon_{j}^{Y N}<1$. Furthermore, $2^{\kappa-1}<1$ and $\left(Y_{j} / Y\right)^{\kappa}<1$.

Proof of Proposition 2. According to Lemmas 6 and 7 it holds that $w_{u_{j}}^{j}<0, w_{Y}^{j}>0$, and $y_{u_{j}}<0$ for $j=A, B$. Hence, $\left.\left(\partial w_{j} / \partial u_{k}\right)\right|_{\mathrm{wS}^{j}}=w_{Y}^{j} y_{u_{k}}<0, j \neq k$ and $j, k=A, B$. Moreover, $\left.\left(\partial w_{j} / \partial u_{j}\right)\right|_{\mathrm{WS}^{j}}=w_{u_{j}}^{j}+w_{Y}^{j} y_{u_{j}}<0$.

Proof of Proposition 3. For Proposition 3 to be true it must hold that $\left|n_{Y}^{B} y_{u_{A}}\right|>$ $\left|w_{Y}^{B} y_{u_{A}}\right|$, implying $w_{Y}^{B}-n_{Y}^{B}<0$. Based on the expression for $w_{Y}^{j}$ in eq. (A.12), it can be computed that

$$
w_{Y}^{j}=-\frac{w_{j} \theta^{j} \mu_{Y}^{j}}{\Psi_{j}}=-\frac{\mu_{Y}^{j} / \mu_{w_{j}}^{j}}{\left\{\mu^{j}\left[\left(1-\tilde{\rho}_{j}\right) \mu^{j} \theta^{j}-1\right] /\left(w_{j} \mu_{w_{j}}^{j}\right)\right\}+1} .
$$

Taking account of eq. (A.10), it follows that $\mu_{Y}^{j} / \mu_{w}^{j}=N_{Y}^{j} / N_{w_{j}}^{j}$. Since $N_{j}=\left(1-u_{j}\right) L$, eq. (A.2) implicitly defines the labor demand function $N^{j}\left(w_{j}, Y\right)$. Applying the implicit function rule leads to

$$
\begin{aligned}
\frac{\partial N^{j} / \partial Y}{\partial N^{j} / \partial w_{j}} & =-\kappa(1-\kappa) a N_{j}^{\beta-1}\left[a N_{j}^{\beta}+(1-a) K_{j}^{\beta}\right]^{\frac{\kappa-\beta}{\beta}}\left(\frac{Y}{2}\right)^{-\kappa} \frac{1}{2} \\
& =-(1-\kappa) \frac{w_{j}}{Y}=-n_{Y}^{j},
\end{aligned}
$$

where the last equality follows from the proof of Lemma 3. Hence,

$$
w_{Y}^{j}=\frac{n_{Y}^{j}}{\left\{\mu^{j}\left[\left(1-\tilde{\rho}_{j}\right) \mu^{j} \theta^{j}-1\right] /\left(w_{j} \mu_{w_{j}}^{j}\right)\right\}+1} .
$$

As stated in the proof of Lemma $6,\left(1-\tilde{\rho}_{j}\right) \mu^{j} \theta^{j} \geq 1$. As a result, the denominator in eq. (A.16) is greater than one, which leads to $w_{Y}^{j}-n_{Y}^{j}<0$, for $j=A, B$.

Proof of Proposition 4. Using the notation of Assumption 4, in country A the variable $x_{A}$ changes, where $x_{A} \in \mathbb{X}_{A}=\left\{\phi_{A}, \chi_{A}, \tilde{\rho}_{A}, \tilde{b}_{A}\right\}$. Bearing in mind eq. (3), the following equation system must be solved:

$$
\mathbf{J}\left(\begin{array}{c}
\partial u_{A} / \partial x_{A} \\
\partial u_{B} / \partial x_{A}
\end{array}\right)=\left(\begin{array}{c}
w_{x_{A}}^{A} \\
0
\end{array}\right)
$$

where the Jacobi matrix $\mathbf{J}$ is defined as

$$
\mathbf{J} \equiv\left(\begin{array}{cc}
\left(n_{u_{A}}^{A}+n_{Y}^{A} y_{u_{A}}\right)-\left(w_{u_{A}}^{A}+w_{Y}^{A} y_{u_{A}}\right) & \left(n_{Y}^{A}-w_{Y}^{A}\right) y_{u_{B}} \\
\left(n_{Y}^{B}-w_{Y}^{B}\right) y_{u_{A}} & \left(n_{u_{B}}^{B}+n_{Y}^{B} y_{u_{B}}\right)-\left(w_{u_{B}}^{B}+w_{Y}^{B} y_{u_{B}}\right)
\end{array}\right) .
$$


Step 1: Determination of the sign of $|\mathbf{J}|$. One obtains

$$
\begin{aligned}
|\mathbf{J}|=[- & \left(n_{u_{A}}^{A}+n_{Y}^{A} y_{u_{A}}\right) w_{u_{B}}^{B}-\left(n_{u_{B}}^{B}+n_{Y}^{B} y_{u_{B}}\right) w_{u_{A}}^{A}+\left(w_{u_{A}}^{A}+w_{Y}^{A} y_{u_{A}}\right) w_{u_{B}}^{B} \\
& \left.+w_{Y}^{B} y_{u_{B}}\left(w_{u_{A}}^{A}-n_{u_{A}}^{A}\right)-n_{u_{B}}^{B} w_{Y}^{A} y_{u_{A}}\right]+n_{u_{B}}^{B}\left(n_{u_{A}}^{A}+n_{Y}^{A} y_{u_{A}}\right)+n_{u_{A}}^{A} n_{Y}^{B} y_{u_{B}} .
\end{aligned}
$$

Recalling the signs of the derivatives from Lemma 3, Lemma 6, Lemma 7, Proposition 1 and Proposition 2, it becomes clear that all terms in brackets are positive. Hence, $n_{u_{B}}^{B}\left(n_{u_{A}}^{A}+n_{Y}^{A} y_{u_{A}}\right)+n_{u_{A}}^{A} n_{Y}^{B} y_{u_{B}}>0$ is a sufficient condition for $|\mathbf{J}|>0$. Using the expressions for $n_{u_{j}}^{j}$ and $n_{Y}^{j}$ from Lemma 3 and $y_{u_{j}}$ from Lemma 7 , one obtains

$$
\begin{aligned}
n_{u_{B}}^{B}\left(n_{u_{A}}^{A}+n_{Y}^{A} y_{u_{A}}\right)+n_{u_{A}}^{A} n_{Y}^{B} y_{u_{B}}=n_{u_{A}}^{A} n_{u_{B}}^{B}\left[1+\frac{n_{Y}^{A} y_{u_{A}}}{n_{u_{A}}^{A}}+\frac{n_{Y}^{B} y_{u_{B}}}{n_{u_{B}}^{B}}\right] \\
=n_{u_{A}}^{A} n_{u_{B}}^{B}\left[1-2^{\kappa-1}\left(\Lambda_{A}\left(\frac{Y_{A}}{Y}\right)^{\kappa}+\Lambda_{B}\left(\frac{Y_{B}}{Y}\right)^{\kappa}\right)\right],
\end{aligned}
$$

where

$$
\Lambda_{j} \equiv \frac{(1-\kappa) \varepsilon_{j}^{Y N}}{(1-\beta)-(\kappa-\beta) \varepsilon_{j}^{Y N}} \quad j=A, B .
$$

Due to the proof of Proposition 1 it holds that $(1-\beta)-(\kappa-\beta) \varepsilon_{j}^{Y N}>(1-\kappa) \varepsilon_{j}^{Y N}$. Hence, $\Lambda_{j}<1$. From Lemma 7 it is easily derived that $Y^{\kappa}=2^{\kappa-1}\left(Y_{A}^{\kappa}+Y_{B}^{\kappa}\right)$. Therefore

$$
2^{\kappa-1}\left[\Lambda_{A}\left(\frac{Y_{A}}{Y}\right)^{\kappa}+\Lambda_{B}\left(\frac{Y_{B}}{Y}\right)^{\kappa}\right]<1 .
$$

This implies $n_{u_{B}}^{B}\left(n_{u_{A}}^{A}+n_{Y}^{A} y_{u_{A}}\right)+n_{u_{A}}^{A} n_{Y}^{B} y_{u_{B}}>0$. As a result, $|\mathbf{J}|>0$.

Step 2: Solution of the system in eq. (A.17). One obtains

$$
\frac{\partial u_{A}}{\partial x_{A}}=\frac{1}{|\mathbf{J}|} w_{x_{A}}^{A}\left[\left(n_{u_{B}}^{B}+n_{Y}^{B} y_{u_{B}}\right)-\left(w_{u_{B}}^{B}+w_{Y}^{B} y_{u_{B}}\right)\right] .
$$

From Propositions 1 and 2 it follows that the expression in brackets is positive. Hence, $\operatorname{sign}\left(\partial u_{A} / \partial x_{A}\right)=\operatorname{sign}\left(w_{x_{A}}^{A}\right)$. It also holds that

$$
\frac{\partial u_{B}}{\partial x_{A}}=\frac{1}{|\mathbf{J}|} w_{x_{A}}^{A}\left(w_{Y}^{B}-n_{Y}^{B}\right) y_{u_{A}},
$$

where $y_{u_{A}}<0$ due to Lemma 7. Bearing in mind Proposition 3, it holds that $w_{Y}^{B}-n_{Y}^{B}<0$. Hence, $\operatorname{sign}\left(\partial u_{B} / \partial x_{A}\right)=\operatorname{sign}\left(w_{x_{A}}^{A}\right)$. The comparative-static effects on real wages can be determined by considering the labor demand equations. One obtains for country $A$ :

$$
\frac{\partial w_{A}}{\partial x_{A}}=\left(n_{u_{A}}^{A}+n_{Y}^{A} y_{u_{A}}\right) \frac{\partial u_{A}}{\partial x_{A}}+n_{Y}^{A} y_{u_{B}} \frac{\partial u_{B}}{\partial x_{A}} .
$$


Due to Proposition $1, n_{u_{A}}^{A}+n_{Y}^{A} y_{u_{A}}>0$. Furthermore, $n_{Y}^{A}>0$ and $y_{u_{B}}<0$ due to Lemma 3 and Lemma 7, respectively. According to the results above, $\partial u_{A} / \partial x_{A}$ and $\partial u_{B} / \partial x_{A}$ have the same sign. The sign of $\partial w_{A} / \partial x_{A}$ therefore is not immediately obvious. Taking account of the solutions for the change in unemployment leads to:

$$
\frac{\partial w_{A}}{\partial x_{A}}=\frac{w_{x_{A}}^{A}}{|\mathbf{J}|}\left\{n_{u_{B}}^{B}\left(n_{u_{A}}^{A}+n_{Y}^{A} y_{u_{A}}\right)+n_{u_{A}}^{A} n_{Y}^{B} y_{u_{B}}-w_{u_{B}}^{B}\left(n_{u_{A}}^{A}+n_{Y}^{A} y_{u_{A}}\right)-n_{u_{A}}^{A} w_{Y}^{B} y_{u_{B}}\right\} .
$$

It has been shown above in Step 1 that $n_{u_{B}}^{B}\left(n_{u_{A}}^{A}+n_{Y}^{A} y_{u_{A}}\right)+n_{u_{A}}^{A} n_{Y}^{B} y_{u_{B}}>0$. From Lemma 6 follows $w_{u_{B}}^{B}<0$ and $w_{Y}^{B}>0 . n_{u_{A}}^{A}>0$ and $y_{u_{B}}<0$ hold due to Lemma 3 and Lemma 7 , respectively. Therefore, $\operatorname{sign}\left(\partial w_{A} / \partial x_{A}\right)=\operatorname{sign}\left(w_{x_{A}}^{A}\right)$. The change in real wages in country $B$ is given by

$$
\frac{\partial w_{B}}{\partial x_{A}}=\left(n_{u_{B}}^{B}+n_{Y}^{B} y_{u_{B}}\right) \frac{\partial u_{B}}{\partial x_{A}}+n_{Y}^{B} y_{u_{A}} \frac{\partial u_{A}}{\partial x_{A}}=\frac{w_{x_{A}}^{A}}{|\mathbf{J}|}\left(n_{u_{B}}^{B} w_{Y}^{B}-n_{Y}^{B} w_{u_{B}}^{B}\right) y_{u_{A}} .
$$

From the signs of the partial derivatives in Lemma 3 and Lemma 6 it immediately follows that $n_{u_{B}}^{B} w_{Y}^{B}-n_{Y}^{B} w_{u_{B}}^{B}>0$. Since $y_{u_{A}}<0, \operatorname{sign}\left(\partial w_{B} / \partial x_{A}\right)=-\operatorname{sign}\left(w_{x}^{A}\right)$. The respective sign of $w_{x_{A}}^{A}$ can be taken from Lemma 6. Then Proposition 4 follows.

Proof of Corollary 1. i) Consider the case of an adverse labor market shock in country $A$. Due to Proposition $4, u_{A}$ and $u_{B}$ increase. Since the stock of capital is fixed, it immediately follows that $Y_{A}, Y_{B}$ and hence also $Y$ decline. For the impact on relative prices, consider the first-order condition for firm's labor demand in the proof of Lemma 2, which can be written as $\kappa p_{i j} \frac{\partial Y_{i j}}{\partial N_{i j}}=w_{i j}$. An adverse labor market shock in country $A$ leads to a decline in employment in country $B$, which implies an increase in the marginal product of labor. Since $w_{i B}$ declines for all $i$, it can be concluded that $p_{i B}$ and hence $p_{B}$ must have decreased. Moreover, $p_{A}$ must have increased since it is not possible that in both countries prices decline relative to the aggregate price level. From the national goods demand functions follows that $Y_{A} / Y_{B}=\left(p_{B} / p_{A}\right)^{\frac{1}{1-\kappa}}$, where $1 /(1-\kappa)=\eta$ denotes the elasticity of substitution between goods. Since $p_{B} / p_{A}$ declines, it follows that $Y_{A} / Y_{B}$ declines. As a result, $Y_{A}$ declines by more than $Y_{B}$. ii) For a positive labor market shock the same reasoning applies, but the signs have to be reversed, i.e. $u_{A}$ and $u_{B}$ decline, $Y_{A}$ and $Y_{B}$ increase, $p_{A}$ decreases, $p_{B}$ increases, $p_{A} / p_{B}$ declines, and $Y_{A} / Y_{B}$ increases, which implies that $Y_{A}$ increases by more than $Y_{B}$.

Proof of Proposition 5. According to the Proposition it must hold that $\left|n_{Y}^{B} y_{u_{A}}\right|=$ $\left|w_{Y}^{B} y_{u_{A}}\right|$, implying $w_{Y}^{B}-n_{Y}^{B}=0$ if $\tilde{b}_{j}=0$. From the wage-setting equation in the proof of Lemma 6 it is evident that with $\tilde{b}_{j}=0$ and $\tilde{\rho}_{j}=\rho_{j}$ one obtains $\left(1-\rho_{j}\right)-$ $\left[\mu^{j}\left(w_{j}, Y, \phi_{j}, \chi_{j}\right) \theta^{j}\left(u_{j}\right)\right]^{-1}=0$. Hence, $\left(1-\rho_{j}\right) \mu^{j} \theta^{j}=1$. It then follows from eq. (A.14) 
that $w_{Y}^{j}=-\mu_{Y}^{j} / \mu_{w_{j}}^{j}=n_{Y}^{j}$, where the last equality follows from the proof of Proposition 3 . As a result, $w_{Y}^{j}-n_{Y}^{j}=0$, for $j=A, B$.

Proof of Proposition 6. Bearing Proposition 5 in mind, it follows from eq. (A.24) that $\partial u_{B} / \partial x_{A}=0$. Due to eq. (A.23) it also follows that $\partial u_{A} / \partial x_{A}=|\mathbf{J}|^{-1} w_{x}^{A}\left(n_{u_{B}}^{B}-\right.$ $\left.w_{u_{B}}^{B}\right)$. Since $n_{u_{B}}^{B}>0$ and $w_{u_{B}}^{B}<0, \operatorname{sign}\left(\partial u_{A} / \partial x_{A}\right)=\operatorname{sign}\left(w_{x_{A}}^{A}\right)$. Eq. (A.25) becomes $\partial w_{A} / \partial x_{A}=\left(n_{u_{A}}^{A}+n_{Y}^{A} y_{u_{A}}\right)\left(\partial u_{A} / \partial x_{A}\right)$. Due to Proposition $1,\left(n_{u_{A}}^{A}+n_{Y}^{A} y_{u_{A}}\right)>0$. As a result, $\operatorname{sign}\left(\partial w_{A} / \partial x_{A}\right)=\operatorname{sign}\left(w_{x_{A}}^{A}\right)$. Furthermore, $\partial w_{B} / \partial x_{A}=n_{Y}^{B} y_{u_{A}}\left(\partial u_{A} / \partial x_{A}\right)$, where $n_{Y}^{B} y_{u_{A}}<0$ because of Lemma 3 and Lemma 7 . Hence, $\operatorname{sign}\left(\partial w_{B} / \partial x_{A}\right)=-\operatorname{sign}\left(w_{x_{A}}^{A}\right)$.

Proof of Proposition 7. It has to be shown that $\left|n_{Y}^{B} y_{u_{A}}\right|>\left|w_{Y}^{B} y_{u_{A}}\right|$, implying $w_{Y}^{B}-$ $n_{Y}^{B}<0$. Since $\tilde{\rho}_{j}=0$, the expression $\Psi_{j}$ defined in the proof of Lemma 6 simplifies to $\widetilde{\Psi}_{j} \equiv \mu^{j} \theta^{j}\left(\mu^{j} \theta^{j}-1\right)+w_{j} \theta^{j} \mu_{w_{j}}^{j}>0$. It then follows from eq. (A.12) that

$$
w_{Y}^{j}=-\frac{w_{j} \theta^{j} \mu_{Y}^{j}}{\widetilde{\Psi}_{j}}=-\frac{\mu_{Y}^{j} / \mu_{w_{j}}^{j}}{\left\{\mu^{j}\left(\mu^{j} \theta^{j}-1\right) /\left(w_{j} \mu_{w_{j}}^{j}\right)\right\}+1} .
$$

Along the lines of the proof of Proposition 3, it is easily seen that $w_{Y}^{j}$ can be written as $w_{Y}^{j}=n_{Y}^{j} /\left\{\left[\mu^{j}\left(\mu^{j} \theta^{j}-1\right) /\left(w_{j} \mu_{w_{j}}^{j}\right)\right]+1\right\}$. Since the denominator is greater than one, it follows that $w_{Y}^{j}-n_{Y}^{j}<0$.

Proof of Proposition 9. According to Proposition 2, the slope of the wage-setting curve is $w_{u_{j}}^{j}+w_{Y}^{j} y_{u_{j}}$. Shifts of the wage-setting curve due to the aggregate income effect are given as $w_{Y}^{j} y_{u_{k}}$ for $j, k=A, B$ and $j \neq k$. The expression $\Psi_{j}$, defined in the proof of Lemma 6 , is smaller than the expression $\widetilde{\Psi}_{j}$, which has been defined in the proof of Proposition 7 . Hence, if $\Psi_{j}$ in Lemma 6 is replaced by $\widetilde{\Psi}_{j}$, it is immediately evident that $\left.\left|w_{u_{j}}^{j}\right|_{\mathrm{FRB}}|<| w_{u_{j}}^{j}\right|_{\text {two-tier }} \mid$ and $\left.w_{Y}^{j}\right|_{\mathrm{FRB}}<\left.w_{Y}^{j}\right|_{\text {two-tier. }}$. From this the Proposition follows. 


\section{References}

Abowd, J. A., and Lemieux, T. (1993). The Effects of Product Market Competition on Collective Bargaining Agreements: The Case of Foreign Competition in Canada. Quarterly Journal of Economics, 108, 983-1014.

Atkinson, A., and Micklewright, J. (1991). Unemployment Compensation and Labor Market Transitions: A Critical Review. Journal of Economic Literature, 29, 16791727.

Beissinger, T. (2002). Unemployment Compensation, Real Wages and Unemployment. Habilitationsschrift, University of Regensburg.

Beissinger, T., and Büsse, O. (2001). Bismarck Versus Beveridge: Which Unemployment Compensation System Is More Prone to Labor Market Shocks? FinanzArchiv, 58, $78-102$.

Beissinger, T., and Egger, H. (2001). Dynamic Wage Bargaining if Benefits are Tied to Individual Wages. IZA Discussion Paper No. 389, Bonn.

Blanchard, O., and Kiyotaki, N. (1987). Monopolistic Competition and the Effects of Aggregate Demand. American Economic Review, 77, 647-666.

Blanchard, O., and Wolfers, J. (2000). The Role of Shocks and Institutions in the Rise of European Unemployment: The Aggregate Evidence. Economic Journal, 110, C1-C33.

Bräuninger, M. (2000). Unemployment Insurance, Wage Differentials and Unemployment. FinanzArchiv, 57, 485-501.

Calmfors, L., and Driffill, J. (1988). Bargaining Structure, Corporatism and Macroeconomic Performance. Economic Policy, 6, 14-61.

Chung, J. W. (1994). Utility and Production Functions. Cambridge, Mass. and Oxford: Blackwell Publishers.

Danthine, J.-P., and Hunt, J. (1994). Wage Bargaining Structure, Employment and Economic Integration. Economic Journal, 104, 528-541.

Dixit, A. K., and Stiglitz, J. E. (1977). Monopolistic Competition and Optimum Product Diversity. American Economic Review, 67, 297-308.

Dutt, A. K., and Sen, A. (1997). Union Bargaining Power, Employment, and Output in a Model of Monopolistic Competition with Wage Bargaining. Journal of Economics, $65,1-17$.

Egger, H. (2002). Unemployment May Be Lower if Unions Bargain over Wages and Employment. Labour, 16, 103-133. 
Flanagan, R. J. (1999). Macroeconomic Performance and Collective Bargaining: An International Perspective. Journal of Economic Literature, 37, 1150-1175.

Goerke, L. (2000). Bismarck versus Beveridge. Flat- and Earnings-Related Unemployment Insurance in an Efficiency Wage Framework. FinanzArchiv, 57, 243-260.

Goerke, L., and Madsen, J. B. (2002). Earnings-Related Unemployment Benefits and Unemployment, mimeo.

Hamermesh, D. S. (1993). Labor Demand. Princeton, New Jersey: Princeton University Press.

Heer, B., and Morgenstern, A. (2000). Indexation of Unemployment Benefits to Previous Earnings, Employment and Wages. Muenchener Wirtschaftswissenschaftliche Beitraege No. 00-13.

Holmlund, B. (1998). Unemployment Insurance in Theory and Practice. Scandinavian Journal of Economics, 100, 113-141.

Layard, R., and Nickell, S. (1990). Is Unemployment Lower If Unions Bargain Over Employment? Quarterly Journal of Economics, 105, 773-787.

Layard, R., Nickell, S., and Jackman, R. (1991). Unemployment. Oxford: Oxford University Press.

Ljungquist, L., and Sargent, T. J. (1998). The European Unemployment Dilemma. Journal of Political Economy, 106, 514-550.

Manning, A. (1991). The Determinants of Wage Pressure: Some Implications of a Dynamic Model. Economica, 58, 325-340.

Manning, A. (1993). Wage Bargaining and the Phillips Curve: The Identification and Specification of Aggregate Wage Equations. Economic Journal, 103, 98-118.

Manning, A. (1998). Comment on B. Holmlund, "Unemployment Insurance in Theory and Practice". Scandinavian Journal of Economics, 100, 143-145.

Nickell, S. (1997). Unemployment and Labor Market Rigidities: Europe Versus North America. Journal of Economic Perspectives, 11, 55-74.

Nickell, S. (1999). Product Markets and Labour Markets. Labour Economics, 6, 1-20.

Nickell, S., and Layard, R. (1999). Labor Market Institutions and Economic Performance. In O. Ashenfelter and D. Card (Eds.), Handbook of Labor Economics, Vol. 3 (pp. 3029-3084). Amsterdam etc: Elsevier.

OECD. (1999). Benefit Systems and Work Incentives (1999 ed.). Paris.

Pissarides, C. A. (1998). The Impact of Employment Tax Cuts on Unemployment and Wages; The Role of Unemployment Benefits and Tax Structure. European Economic Review, 42, 155-183. 
Schluter, C. (1997). On the Performance of Social Benefit Systems. Economic Journal, 107, 489-502.

Weitzman, M. L. (1985). The Simple Macroeconomics of Profit Sharing. American Economic Review, 75, 937-953. 


\section{IZA Discussion Papers}

\begin{tabular}{|c|c|c|c|c|}
\hline No. & Author(s) & Title & Area & Date \\
\hline 640 & $\begin{array}{l}\text { J. Hartog } \\
\text { N. Jonker } \\
\text { H. van Ophem }\end{array}$ & $\begin{array}{l}\text { Dual Track or Academic Route for Auditors: } \\
\text { Does It Matter? }\end{array}$ & 6 & $11 / 02$ \\
\hline 641 & $\begin{array}{l}\text { J. Hartog } \\
\text { L. Diaz Serrano }\end{array}$ & $\begin{array}{l}\text { Earning Risk and Demand for Higher Education: } \\
\text { A Cross-Section Test for Spain }\end{array}$ & 2 & $11 / 02$ \\
\hline 642 & $\begin{array}{l}\text { J. Hartog } \\
\text { A. Zorlu }\end{array}$ & $\begin{array}{l}\text { The Effect of Immigration on Wages in Three } \\
\text { European Countries }\end{array}$ & 1 & $11 / 02$ \\
\hline 643 & $\begin{array}{l}\text { A. Björklund } \\
\text { M. Sundström }\end{array}$ & $\begin{array}{l}\text { Parental Separation and Children's Educational } \\
\text { Attainment: A Siblings Approach }\end{array}$ & 6 & $11 / 02$ \\
\hline 644 & $\begin{array}{l}\text { J. D. Brown } \\
\text { J. S. Earle }\end{array}$ & $\begin{array}{l}\text { Job Reallocation and Productivity Growth Under } \\
\text { Alternative Economic Systems and Policies: } \\
\text { Evidence from the Soviet Transition }\end{array}$ & 4 & $11 / 02$ \\
\hline 645 & $\begin{array}{l}\text { M. Karanassou } \\
\text { H. Sala } \\
\text { D. J. Snower }\end{array}$ & $\begin{array}{l}\text { Long-Run Inflation-Unemployment Dynamics: } \\
\text { The Spanish Phillips Curve and Economic Policy }\end{array}$ & 3 & $11 / 02$ \\
\hline 646 & $\begin{array}{l}\text { L. Graham } \\
\text { D. Snower }\end{array}$ & The Return of the Long-Run Phillips Curve & 3 & $11 / 02$ \\
\hline 647 & $\begin{array}{l}\text { C. Grund } \\
\text { D. Sliwka }\end{array}$ & Envy and Compassion in Tournaments & 1 & $11 / 02$ \\
\hline 648 & $\begin{array}{l}\text { C. Schnabel } \\
\text { T. Schank } \\
\text { J. Wagner }\end{array}$ & $\begin{array}{l}\text { Works Councils - Sand or Grease in the } \\
\text { Operation of German Firms? }\end{array}$ & 3 & $11 / 02$ \\
\hline 649 & $\begin{array}{l}\text { J. van Ours } \\
\text { J. Veenman }\end{array}$ & $\begin{array}{l}\text { From Parent to Child: Early Labor Market } \\
\text { Experiences of Second-Generation Immigrants } \\
\text { in the Netherlands }\end{array}$ & 1 & $11 / 02$ \\
\hline 650 & $\begin{array}{l}\text { H. Battu } \\
\text { P. J. Sloane }\end{array}$ & Overeducation and Ethnic Minorities in Britain & 2 & $11 / 02$ \\
\hline 651 & E. Schlicht & $\begin{array}{l}\text { Social Evolution, Corporate Culture, and } \\
\text { Exploitation }\end{array}$ & 3 & $11 / 02$ \\
\hline 652 & E. Plug & $\begin{array}{l}\text { How Do Parents Raise the Educational } \\
\text { Attainment of Future Generations? }\end{array}$ & 5 & $11 / 02$ \\
\hline 653 & $\begin{array}{l}\text { W. Groot } \\
\text { E. Plug } \\
\text { H. Maassen van den } \\
\text { Brink }\end{array}$ & $\begin{array}{l}\text { Money for Health: The Compensating Variation } \\
\text { of Cardiovascular Diseases }\end{array}$ & 6 & $11 / 02$ \\
\hline 654 & $\begin{array}{l}\text { C. Ruhm } \\
\text { U. G. Gerdtham }\end{array}$ & $\begin{array}{l}\text { Deaths Rise in Good Economic Times: Evidence } \\
\text { From the OECD }\end{array}$ & 2 & $11 / 02$ \\
\hline 655 & $\begin{array}{l}\text { W. Arulampalam } \\
\text { R. A. Naylor } \\
\text { J. P. Smith }\end{array}$ & $\begin{array}{l}\text { Effects of In-Class Variation and Student Rank } \\
\text { on the Probability of Withdrawal: Cross-Section } \\
\text { and Time-Series Analysis for UK University } \\
\text { Students }\end{array}$ & 2 & $11 / 02$ \\
\hline 656 & $\begin{array}{l}\text { T. Beissinger } \\
\text { O. Büsse }\end{array}$ & $\begin{array}{l}\text { The Impact of the Unemployment Benefit } \\
\text { System on International Spillover Effects }\end{array}$ & 2 & $11 / 02$ \\
\hline
\end{tabular}

